\title{
Escherichia Coli Content in Refill Drinking Water (AMIU) in Samatiga District, West Aceh Regency
}

\author{
${ }^{1}$ Azwar, ${ }^{1}$ Safrida, ${ }^{1}$ Yarmaliza, ${ }^{1}$ Fitrah Reynaldi, ${ }^{1}$ Arfah Husna, ${ }^{1}$ Arif Iskandar \\ ${ }^{1}$ Faculty of Public Health, Universitas Teuku Umar, Aceh, Indonesia \\ Coresponding author: Azwar, e-mail: azwar@utu.ac.id
}

Co-author : SS: safrida@gmail.com, YY: yarmaliza@utu.ac.id, FR: fitrahreynaldi@utu.ac.id,

AF: arfahhusna@utu.ac.id, AI: arifiskandar@utu.ac.id

Submitted: 16/09/2020 Revised: 02/10/2020 Accepted: 19/10/2020 Published online: 21/10/2020

doi: https://doi.org/10.35308/j-kesmas.v7i2.2533 How to cite this article: Azwar. A., Safrida, S., Yarmaliza, Y., Reynaldi, F., Husna, A., \& Iskandar, A. (2020). Escherichia Coli Content in Refill Drinking Water (AMIU) in Samatiga District, West Aceh Regency. J-Kesmas: Jurnal Fakultas Kesehatan Masyarakat (The Indonesian Journal of Public Health), 7(2), 69-73.

\begin{abstract}
The quality of drinking water supply must be guaranteed. The WHO (World Health Organization) determines water quality by means of E. Coli bacteria. Based on the Minister of Health Regulation No. 492 / MENKES / PER / IV / 2010 The maximum permissible content of E. Coli in drinking water is 0 per $100 \mathrm{ml}$. The presence of E. coli in water is an indicator of human and animal fecal pollution that can cause diarrhea and even death. Selection of Refillable Drinking Water (AMIU) as an alternative to fulfill drinking water needs is a risk that can endanger health if the quality of AMIU is added if consumers do not pay attention to safety and hygiene. This study aims to see the content of E. coli in Refill Drinking Water (AMIU) in Samatig a District, West Aceh Regency. This research is experimental with cross sectional design using quantitative laboratory examination with the Most Probable Number (MPN) method. The population in this study were all refill drinking water depots that did not have a drinking certificate in Samatiga District, West Aceh Regency. The research sample used a total sampling method of 7 refill drinking water depots. The results of the analysis showed that from all samples as many as 6 samples (85.71\%) tested positive for Escherichia coli bacteria and 1 sample (14.29\%) tested negative for Escherichia coli bacteria. Based on the calculation of the number of colonies with the MPN / $100 \mathrm{ml}$ table then comparing with the requirements of the Regulation of the Minister of Health of the Republic of Indonesia Number 492 / Menkes / Per / IV / 2010 concerning drinking water quality requirements that the 6 samples tested positive were not suitable for consumption.
\end{abstract}

Keywords: Escherichia coli, water drinking refill (AMIU), MPN.

\section{Introduction}

Clean water is a necessity that is absolutely necessary for humans. Water is always used in daily life whether cooking, washing, bathing and so on. To maintain human life, we must be able to meet the need for clean water, especially drinking water. Approximately 2.5-3 liters of drinking water that must be consumed by humans every day and if it is not enough, it can have fatal consequences for the health of the human body (Sari, 2016). The importance of water for health can be seen from the amount of water in the organs, such as $80 \%$ of blood is water, losing $15 \%$ of body weight can result in death. Drinking water is water of which quality meets health requirements and can be drunk directly, the health requirements referred to are microbiological, chemical, physical and radio active (Walangitan, Sapulete and Pangemanan, 2016). Microbiological parameters are one of the factors that must receive attention because of their dangerous impact, which can cause infectious diseases (Suriadi, Husaini and Marlinae, 2016). The incidence of direct airborne diseases is still in the top five in the world. Microbiological pollution, especially a common symptom that occurs in many air sources around settlements. As an illustration, in developing countries mortality due to diarrhea including cholera in 2002 reached 1.8 million and $90 \%$ occurred in infants and toddlers. As many as $88 \%$ of cases of diarrhea related to unsafe air, hygiene and sanitation that do not meet health requirements (Puspitasari, Hikmah and Rahman, 2020).

The quality and quantity of drinking water must be guaranteed. The provision of clean water for household purposes such as drinking water must meet the requirements stipulated by international or national regulations (Akili, Asrifuddin and Punuh, 2017). Sanitation hygiene requirements in drinking water management cover at least the following aspects: place, equipment, and handlers (Jufri, 2019). The quality of drinking water in Indonesia must meet the requirements set out in the Minister of Health Regulation No. 492 / MENKES / PER / IV / 2010 where each component allowed in it must comply 
with the health requirements of drinking water which include physical, chemical and biological requirements(Permenkes RI No. 492 Tahun 2010). The need for drinking water continues to increase in line with population growth so that it can be balanced with the availability of clean water. The fulfillment of people's drinking water needs varies widely. A small proportion of people in meeting their drinking water needs consume Bottled Drinking Water (AMDK) because it is practical and is considered more hygienic. In general, people currently consume a lot of Refillable Drinking Water (AMIU) produced by the Refill Drinking Water Depot (DAMIU), the price is cheaper and more practical. This is the main answer why people prefer AMIU to meet their drinking water needs(Mairizki, 2017).

Since 1999, DAMIU has begun to emerge which provides ready-to-drink water and has begun to spread in every region. Refill drinking water depots are industries that process raw water into drinking water and sell it directly to buyers. Refill drinking water (AMIU) is drinking water obtained from refill places that come from clean water sources. Then the water is processed through a process of chlorination, aeration, filtration and irradiation with ultra violet light (Winandar, Muhammad and Irmansyah, 2020).

The Refill Drinking Water depot business is considered as an alternative opportunity, because it requires a small but profitable investment, especially for consumers because the price of refill drinking water is cheaper than branded bottled drinking water. The choice of AMIU as an alternative to fulfill drinking water needs is a risk that can endanger health if the quality of AMIU is still in doubt, especially if consumers do not pay attention to safety and hygiene. The quality of AMIU has recently declined due to general problems, including equipment for Refill Drinking Water Depot which is not equipped with sterilization equipment, has low killing power against bacteria, or the employer does not know; the quality of the raw water used, the type of DAMIU equipment that is good and how it is maintained and the handling of treated water (Mairizki, 2017).

The community still has the perception that this refill drinking water depot comes from mountain springs that meet health requirements. In reality this is not the case, raw water can be taken from various sources including groundwater, rivers, mountain water and sea water. Efforts must be made to provide safe drinking water, because of the possibility of contaminating microorganisms in drinking water.
Based on the Minister of Health Regulation No. 32 of 2017 in terms of water quality must include physical, chemical, biological parameters which can be mandatory parameters and additional parameters. (Winandar, Muhammad and Irmansyah, 2020). WHO (World Health Organization) determines water quality is biologically determined by the presence of E. Coli bacteria. The maximum permissible content of E. Coli in drinking water is 0 per $100 \mathrm{ml}$ (Simanjuntak, Hasan and Naria, 2018)

The results of research conducted (Risti Iriani Saba, Sri Seprianto Maddusa and Jootje ML Umboh, 2019) on Sanitation Hygiene and Bacterial Content in Refill Drinking Water Depots (DAMIU) in the Aertembaga Health Center Work Area, Bitung City, showed that the Escherichia coli content from nine water depots for refills, there are two DAMIU containing E. coli bacteria, namely depot I 2.2 / 100 $\mathrm{ml}$ and depot III $5.1 / 100 \mathrm{ml}$.

A similar study was conducted by (Winandar, Muhammad and Irmansyah, 2020) regarding the Analysis of Escherichia coli in Refillable Drinking Water at a Drinking Water Depot (DAM) in the Kuta Alam Community Health Center in Banda Aceh, it was found that refill drinking water that was positive contained Eschericia coli from 11 The sample under study contained 4 samples, namely $36 \%$, and those that were negative containing Eschericia coli were 7 samples, namely $64 \%$. Of the 11 DAMIU studied, all samples $(100 \%)$ used PDAM water as their raw water source.

Based on data obtained from the West Aceh District Health Office in 2018 the number of refill drinking water depots was 150 depots scattered in each District, while data from the Samatiga Health Center in 2018 there were 10 refill drinking water depots in Samatiga District and in 2019 increased to 11 depot. Based on a preliminary survey conducted on 11 depots in Samatiga Subdistrict, Aceh Regency, it was found that not all depots were supervised, of the 11 depots that were operating only 4 had been monitored and received a drinking certificate, while 7 more depots had not received supervision and have a certificate of proper drinking (Dinkes, 2019). Therefore, it is necessary to conduct research aimed at determining the content of $\mathrm{E}$. coli in Refill Drinking Water (AMIU) in Samatiga District, West Aceh Regency.

\section{Materials and Methods}

This research is experimental with a cross sectional design, in which the researcher directly observes the object to be studied, then describes 
descriptively to determine the presence of Escherichia coli bacteria in refill drinking water samples in Sama Tiga District, West Aceh Regency using quantitative laboratory tests with the Most Probable method. Number (MPN). The population in this study were all refill drinking water depots that had not received a certificate of proper drinking in in Samatiga District, West Aceh Regency.The research sample used a total sampling method, namely 7 depots of drinking water refill.

\section{Results}

There The quantitative research was carried out by the Meulaboh Regional Health Laboratory, West Aceh Regency. The results of the Most Probable Number (MPN) test on 7 refill drinking water samples in Samatiga District, West Aceh Regency can be seen in the following table:

Table 1. The results of the qualitative analysis of Escherichia coli bacteria

\begin{tabular}{|c|c|c|c|c|c|}
\hline \multirow[t]{2}{*}{ No } & \multirow[t]{2}{*}{ Sample Code } & \multicolumn{3}{|c|}{$\begin{array}{l}3 \text { Series of Tubes in Qualitative } \\
\text { Coliform Assumption Test }\end{array}$} & \multirow{2}{*}{$\begin{array}{l}\text { MPN Escherichia } \\
\text { collioomi sample }\end{array}$} \\
\hline & & $10 \mathrm{mg}$ & $1 \mathrm{mg}$ & $0,1 \mathrm{mI}$ & \\
\hline 1. & AMIU 1 & 3 & 1 & o & 12 \\
\hline 2. & AMIU 2 & 5 & 0 & 1 & 96 \\
\hline 3. & AMIU 3 & O & o & o & O \\
\hline 4. & AMIU 4 & 1 & O & o & 2,2 \\
\hline 5. & AMIU 5 & 5 & 0 & 1 & 96 \\
\hline 6. & AMIU 6 & 1 & 1 & 0 & 4,4 \\
\hline 7. & AMIU 7 & 5 & O & $\mathrm{O}$ & 38 \\
\hline
\end{tabular}

AMIU: Refill Drinking Water

In table 1, it can be seen that the results of the examination of Escherichia coli bacteria in refill drinking water samples in Sama Tiga Subdistrict, West Aceh Regency, only 1 (one) sample does not contain Escherichia coli bacteria with the AMIU sample code 3 while 6 (six) samples others contain Escherichia coli bacteria in different amounts. The highest content of Escherichia coli bacteria was found in samples with AMIU 2 and AMIU 5 codes, which amounted to $96 / 100 \mathrm{ml}$ samples, while the lowest content of Escherichia coli was found in samples with AMIU code 4 which amounted to 2.2 / $100 \mathrm{ml}$ samples.

The percentage results of the qualitative analysis of Escherichia coli bacteria in refill drinking water can be seen in Figure 1.

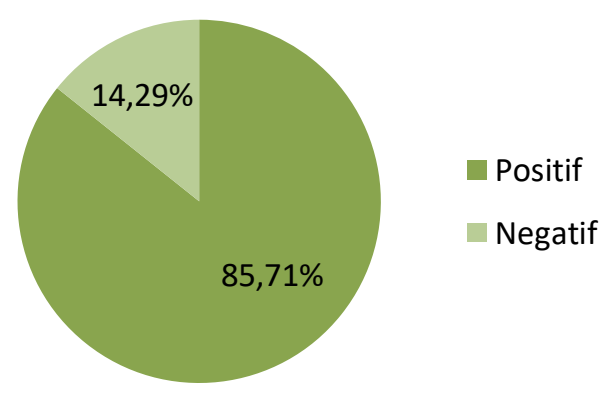

The picture above shows the results of research on refilled drinking water in Sama Tiga District, West Aceh Regency, that of the 7 samples studied, 6 samples $(85.71 \%)$ obtained positive results containing Escherichia coli bacteria and 1 sample (14.29\%) obtained negative results do not contain the
Escherichia coli bacteria

\section{Discussion}

The Most Probable Number (MPN) method is used to estimate the number of bacteria in $100 \mathrm{ml}$ of water in the sample. The advantages of this method are quite easy to do, it can determine the specific number of certain microbes using the appropriate media, this method was chosen to determine the density of Escherichia coli bacteria. The drawback of this method is that it requires a large number of tube tools (Sari, 2016).The results showed that there were 6 (six) out of 7 (seven) samples showing a positive MPN index. There were 2 samples with the highest MPN index, namely AMIU 2 and AMIU 5 samples which contained positive Escherichia coli bacteria in the amount of 96/100 ml samples. The AMIU 7 sample is $38 / 100 \mathrm{ml}$ sample, AMIU 1 is $12 / 100 \mathrm{ml}$ sample, AMIU 6 is 4.4 / $100 \mathrm{ml}$ and the lowest MPN index is found in AMIU 4 sample, which is 2.2 / 100 $\mathrm{ml}$ sample.The presence of Escherichia coli bacteria in drinking water identifies that drinking water has been contaminated with fecal contamination and the water is not safe for consumption (Zikra, Amir and Putra, 2018). The presence of Coliform and Escherichia coli bacteria can be caused by various factors, namely contaminated raw water, transportation systems to transport water from the source to DAMIU, handling of buyers' containers, maintenance of buildings and equipment, condition of DAMIU (DAMIU building sites, construction of Depot buildings concerning Spatial layout and physical requirements), operator knowledge, physical 
water requirements, and others (Hakim, Listiono and Novianti, 2020).DAMIU processing and maintenance equipment can also be one of the causes of bacterial contamination in drinking water(Selomo et al., 2018). Storing water in the reservoir for a long time can also contaminate E. coli, so that this affects the quality of the raw water sources used, so it is very important to pay attention to the cleanliness of the shelter, the processing process and the cleanliness of the environment around DAMIU (Mila, Nabilah and Puspikawati, 2020) Another cause of raw water sources that are at risk of pollution, especially when filling raw water into a transport tanker or when transferring raw water from a tanker to a water storage reservoir (Regia, Ihsan and Tirta, 2020). In addition, handlers can also cause bacterial contamination. To prevent this, hand washing soap in the Refill Drinking Water Depot is needed, this is important because in the hygiene of the handlers when filling drinking water, handlers should first wash their hands with soap, not only with clean water (Novroza et al., 2020). Handlers have more responsibility in keeping DAMIU clean. The active role of handlers and the community in maintaining cleanliness can improve health status (Safrizal and Auliana, 2019).

The requirement for drinking water is that it must be safe to drink, meaning that it is free of pathogenic microbes and harmful substances and is acceptable in terms of color, taste, smell and turbidity(Sudiana and Sudirgayasa, 2020). One of the requirements for clean water that can be consumed is the absence of Coliform and Escherichia coly in 100 $\mathrm{ml}$ of water. Escherichia coli Is the most common normal flora in the intestines of humans and animals. It can turn into a pathogenic opportunist when it lives outside the intestine, which is the normal location where it is located and can cause urinary tract infections, bile ducts, wound infections and mastitis in cattle. E. Coly is one type of coliform organism that is most commonly used as an indicator of contamination originating from human or animal feces and indicates poor sanitary conditions for water and food. (Apriany, Siregar and Girsang, 2019). Bad environments and dirty places can increase bacterial numbers and cause disease. Transmission of the disease occurs through water contaminated with pathogenic bacteria and transmitted to humans by mouth. Common diseases experienced are diarrhea, abdominal pain, typhoid, paratyphoid, dysentery, etc. which are caused by contamination of Escherichia coli, Salmonella, Shigella and Vibrio bacteria in water (Ernawaningtyas, Aziz and Styawan, 2020).

According to (Rongre, Joseph and Pinontoan, 2018) Escherichia coli is a bacterium from the fecal coli bacterial group. E. coli lives in the large intestine of humans and warm-blooded animals. The presence of E. coli in water is an indicator of human and animal fecal contamination, which means the risk of other types of pathogens in water that are dangerous if exposed to humans. The impact of the Escherichia coli bacteria often causes diarrheal diseases, from diarrheal diseases to diarrhea which causes death (Awuy, Sumampouw and Boky, 2018).The existence of the Escherichia coli bacteria is also caused by bad environmental conditions so that it is a factor in causing diarrhea (Alamsyah and Marianthi, 2020).

In accordance with the Regulation of the Minister of Health of the Republic of Indonesia Number 492 / Menkes / Per / IV / 2010 concerning the requirements for the quality of drinking water with a maximum level allowed 0/100 $\mathrm{ml}$. Then the test results that have been obtained by comparing the MPN / $100 \mathrm{ml}$ results with the Regulation of the Minister of Health of the Republic of Indonesia Number 492 / Menkes / Per / IV / 2010 that 85.71\% of samples contain positive Escherichia coli bacteria are declared not meeting the requirements and only $14.29 \%$ the sample meets the requirements based on the Regulation of the Minister of Health of the Republic of Indonesia Number 492 / Menkes / Per / IV / 2010.

\section{Conclusion}

The results of the qualitative analysis showed that of all refill drinking water samples in Samatiga District, West Aceh Regency, 6 samples (85.71\%) were tested positive for Escherichia coli bacteria and 1 sample (14.29\%) tested negative for Escherichia coli bacteria. Based on the calculation of the number of colonies with the MPN / $100 \mathrm{ml}$ table then comparing with the requirements of the Regulation of the Minister of Health of the Republic of Indonesia Number 492 / Menkes / Per / IV / 2010 concerning drinking water quality requirements that 6 samples were declared positive and unfit for consumption, while the samples that were declared negative amounting to 1 sample.

\section{Acknowledgement}

Thanks to the Head of the Samatiga District Health Center and his staff who have helped and accompanied the implementation of this research. 


\section{Author Contribution and Competing Interest}

The authors have their respective contributions in completing this article. The first authors are the main contributors who are responsible for the concept of writing the article as a whole. The next author is a member contributor who is responsible for data analysis and presentation.

\section{Publisher's Note}

J-Kesmas: Jurnal Fakultas Kesehatan Masyarakat (Indonesia Journal of Public Health) remains neutral with regard to jurisdictional claims in published institutional affiliation.

\section{References}

Akili, R. H., Asrifuddin, A. \& Punuh, M. I.(2017). Analisis kandungan bakteri total coliform dalam air bersih dan eschererchia coli dalam air minum pada depot air minum isi ulang di wilayah kerja Puskesmas Tuminting Kota Manado. Jurnal KESMAS, 47-52.

Alamsyah, T. \& Marianthi, D.(2020). Correlation between incidence of diarrhea in toddlers and housewife's clean and healthy lifestyle. $J$ Kesmas: Jurnal Fakultas Kesehatan Masyarakat (The Indonesian Journal of Public Health), 7(1), 57.

Apriany, D., Siregar, S. D. \& Girsang, E. (2019). Hubungan sanitasi dan personal higiene dengan kandungan e-coli pada penjual es doger di Kecamatan Medan Amplas. Jurnal Kesehatan Global, 2(2), 103.

Awuy, S. C., Sumampouw, O. J. \& Boky, H. B. (2018). Kandungan escherichia coli pada air sumur gali dan jarak sumur dengan septic tank di Kelurahan Rap-Rap Kabupaten Minahasa Utara tahun 2018. Jurnal KESMAS, 7(4), 1-2.

Ernawaningtyas, E., Aziz, Y. S. \& Styawan, Q. A. (2020). Uji cemaran mikroba air minum isi ulang dari depot air minum di wilayah Kabupaten Ponorogo', Jurnal MEDFARM: Farmasi dan Kesehatan, 9(1), 8-13.

Jufri, S. O. (2019). Kandungan bakteri penyebab diare (coliform) pada air minum ( studi kasus pada air minum dari depot air minum isi ulang di Kabupaten Minahasa). Journal PHWB, 1(2), 8-13.

Hakim, S., Listiono, H. \& Novianti, L. (2020). Kandungan escherichia coly pada sumber air PDAM depot air minum dan sumur gali. Jurnal Kesehatan dan Pembangunan, 10(19),
107-113.

Kemenkes RI, (2010). Peraturan Menteri Kesehatan Republik Indonesia Nomor:492/MENKES/PER/IV/2010.

Mairizki, F. (2017). Analisa kualitas air minum isi ulang di sekitar kampus Universitas Islam Riau. Jurnal Katalisator, 2(1), 9.

Mila, W., Nabilah, S. L. \& Puspikawati, S. I. (2020). Higiene dan sanitasi depot air minum isi ulang di Kecamatan Banyuwangi Jawa Timur: Kajian Deskriptif. Ikesma, 16(1), 7.

Novroza, H. E. et al. (2020). Hubungan higiene sanitasi kondisi depot air minum dengan kualitas mikrobiologis air minum isi ulang di Kecamatan Banymanik Semarang. Jurnal Kesehatan Masyarakat (e-Journal), 28(2), 143.

Puspitasari, Ka., Hikmah, N. \& Rahman, H. (2020). Studi kualitas bakteriologis depot air minum isi ulang di wilayah kerja puskesmas Tamangapa Kota Makassar', Window of Public Health Journal, 1(1), 16-21.

Regia, R. A., Ihsan, T. \& Tirta, D. D. (2020). Pengendalian kontaminasi total coliform pada depot air minum isi ulang dengan konsep hazard analysis critical control point. Dampak: Jurnal Teknik Lingkungan Universitas Andalas, 1, 9-14.

Risti Iriani Saba, Sri Seprianto Maddusa \& Jootje M.L. Umboh (2019). Higiene sanitasi dan kandungan bakteri pada depot air minum isi ulang (damiu) di wilayah kerja Puskesmas Aertembaga Kota Bitung. Jurnal KESMAS, $8(3), 69-74$

Rongre, A. J. P., Joseph, W. B. S. \& Pinontoan, O. R. (2018). Kandungan escherichia coli dan kondisi fisik sumur gali di Kelurahan Kakaskasen. Jurnal KESMAS, 7(4).

Safrizal, S. \& Auliana, L. (2019). Implementasi pos kesehatan desa di Gampong Ladang Tuha I Kecamatan Lembah Sabil Kabupaten Aceh Barat Daya. J-Kesmas: Jurnal Fakultas Kesehatan Masyarakat (The Indonesian Journal of Public Health), 6(1) 14.

Sari, R. (2016). Analisis kuantitatif bakteri escherichia coli pada air minum isi ulang di wilayah Sungai Besar Kota Banjarbaru. Jurnal Ilmiah Ibnu Sina, 1(1), 26-35.

Selomo, M. et al. (2018). Hygiene dan sanitasi depot air minum isi ulang di Kecamatan Campalagian Kabupaten Polewali Mandar. Jurnal Nasional Ilmu Kesehatan, 1(2), 1-11.

Simanjuntak, B. M. ., Hasan, W. \& Naria, E. (2018). Tingkat hygiene dan kandungan escherichia coli pada air tebu yang dijual sekitar Kota 
Medan. Jurnal Kesehatan, 9(2), 214.

Sudiana, I. M. \& Sudirgayasa, I. G. (2020). Analisis cemaran bakteri coliform dan eschericia coli pada depot air minum isi ulang (DAMIU). Jurnal Kesehatan Bakti Tunas Husada: Jurnal Ilmu Ilmu Keperawatan, Analis Kesehatan dan Farmasi, 20, 52-61.

Suriadi, S., Husaini, H. \& Marlinae, L. (2016). Hubungan hygiene sanitasi dengan kualitas bakteriologis depot air minum (DAM) di Kabupaten Balangan. Jurnal Kesehatan Lingkungan Indonesia, 15(1), 28.

Walangitan, M. R., Sapulete, M. \& Pangemanan, J. (2016). Gambaran kualitas air minum dari depot air minum isi ulang di Kelurahan Ranotana-Weru dan Kelurahan Karombasan Selatan menurut parameter mikrobiologi. Jurnal Kedokteran Komunitas dan Tropik, 4(1).

Winandar, A., Muhammad, R. \& Irmansyah (2020). Analisis escherichia coli dalam air minum isi ulang pada depot air minum (DAM) di wilayah kerja puskesmas Kuta Alam Banda Aceh. Jurnal Sains dan Aplikasi, 8(1), 53-61.

Zikra, W., Amir, A. \& Putra, A. E. (2018). Identifikasi bakteri escherichia coli (e.coli) pada air minum di rumah makan dan cafe di Kelurahan Jati serta Jati Baru Kota Padang. Jurnal Kesehatan Andalas, 7(2), 212-216. 